\title{
Ice Loads on Structures in the Baltic Environment
}

\author{
Jørgen S. Steenfelt \\ COWI, Kongens Lyngby, Denmark \\ E-mail: jos@cowi.com
}

\begin{abstract}
For offshore, nearshore and harbour structures ice loading is often a decisive ULS load. However, the Code requirements, the regulations and design practices vary considerably across the Baltic Sea region and beyond. This result in incommensurable values of the compressive strength of the ice and the resulting recommended/prescribed design loads. The paper examines these differences over time and in-between countries and elucidates the effects on the design for a number of case histories. The Danish rules show a pronounced trend of increasing values of compressive ice strength (five-fold from 1945 to 2015). Surprisingly, this is commensurate with the trend of less severe winters with time. In conclusion, the Danish code requirements need critical review to better match reality and to reduce the cost of foundation structures subject to ice loading.
\end{abstract}

Keywords: ice strength, ice design rules, bridge piers, harbour structures, wind turbine foundations, Ultimate Limit State.

Conference topic: Design experiences and theoretical solutions / Case histories.

\section{Introduction}

Global warming seems irrefutable but we still need to include the effect of ice loading in our design of structures in the marine environment.

The Author's interest in this topic originated from the design of piles for the boardwalk for the new Royal Theatre in Copenhagen (see Fig. 1). The structure is very light and founded on "Venezian piles" raking up to $1: 1$ as per the architect's idea.

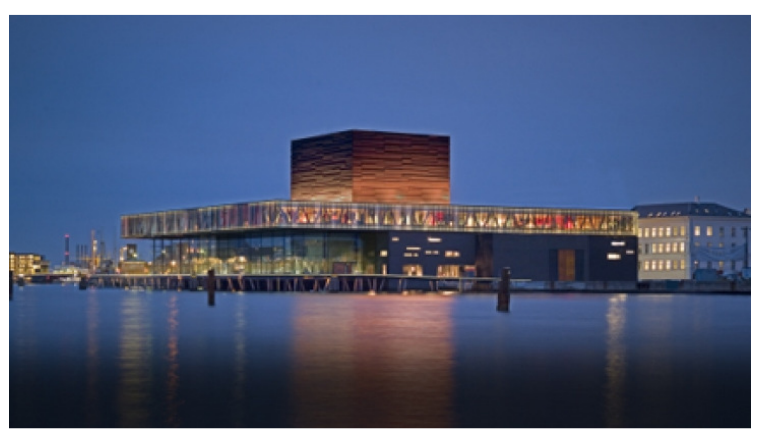

Fig. 1. New Royal Theatre in Copenhagen with "Venetian" piles below the boardwalk

Using the Danish Code of Practise, DS410 (1998), resulted in very high loads incommensurable with the desired slender piles. At the same time (2002/2003), COWI was designing a swing bridge in the harbour of Malmö on the opposite side of Øresund. Here, the characteristic horizontal loads from ice crushing on $\varnothing 813 \mathrm{~mm}$ piles (using Swedish rules) were an order of magnitude smaller than the loads according to the Danish rules.

To allow for a buildable design the rules and recommendations in other countries, particularly the neighbouring Sweden, were investigated. The comparison led to a compromise using a "weighted average" of the Danish and Swedish rules and allowed for a very considerable reduction in ice loading. The reduction was borne out by the fact that failure of piles due to ice loading had never been experienced in Copenhagen Harbour, not even in 1987 where the lowest temperatures over a 30 year period was recorded.

The rationale employed has subsequently been used for several bridge and marine structures in Denmark for re-visit of design (due to upgrade of the structure) or new design considering ice loading. Remarkably, structures designed pre 1982 should have failed due to ice loading according to current rules, but stands proud unaware of the rules.

In the paper the evolvement of the Danish rules over time are summarized and compared with rules from other countries (in terms of the ice strength and the design consequences). The emphasis in the paper is on the horizontal load against structures resulting from dynamic forces due to impact from moving ice sheets or floes driven by current or wind action as the impact from thermal movements of the frozen ice is an order of magnitude smaller.

\section{Evolvement of Danish rules}

The Danish Code of Practice for loads was DS410 prior to adoption of the Eurocode system. In DS410 (1945, and reprints in 1959, 1965) it is stated that the ice load is very much site dependant and general, valid "numbers" cannot be given. However, as a guidance for bridge piers in waterways the ice load may be calculated as a concentrated load in the direction of the current at a value of 1 to $1.5 \mathrm{t}$ ( $\sim 10$ to $15 \mathrm{kN}$ ) per m span width (average between neighbouring piers).

For bridge piers in sounds and inlets the concentrated load may be taken as $\mathrm{P}=3 \mathrm{t}(\sim 30 \mathrm{kN})$ per $\mathrm{m}$ span 
width in the direction of the current and $\mathrm{P} / 5$ in the direction perpendicular to the current.

In the late 1970ies, the Danish rules were formalised to take account of the ice thickness, the shape of the pier or wall and the compressive strength of the ice. The equations were comparable to the present rules stipulated in the addendum regarding ice loading to the Danish Annex to the Eurocode (Banedanmark, Vejdirektoratet 2015):

$$
Q=k_{1} k_{2} k_{3} r_{c} e d
$$

where $Q$ indicates the load on the structure, $r_{c}$, the compressive strength of the ice, $e$, the ice thickness $(=0.32$ $\operatorname{sqrt}\left(\log _{e}(1 / n)-0.4\right)=0.6 \mathrm{~m}$ for $\mathrm{n}=50$ year return period), and $d$, the width of the structure at the water level. The factors $k_{1}, k_{2}, k_{3}$ account for structure shape $\left(k_{1}=\right.$ 1.0 for rectangular and 0.9 for circular $)$, ice contact $\left(k_{2}=\right.$ 0.5 for moving and 1.0 for ice frozen to structure) and ice thickness to structure width $k_{3}$ (see Fig. 11), respectively.

The most notable difference from the 1982 Code to the present time is the change in ice compressive strength as seen in Table 1 . The shape factor, $k_{3}$, has changed very slightly and the ice thickness for $0.02 /$ year occurrence from $0.6 \mathrm{~m}$ to $0.57 \mathrm{~m}$.

Table 1. Ice strength in Danish rules for sea water/fresh water

\begin{tabular}{|c|c|c|c|}
\hline Code, year & $\begin{array}{c}\text { Compressive } \\
\text { strenght } \\
\mathrm{r}_{\mathrm{c}}(\mathrm{kPa}) \\
\end{array}$ & $\begin{array}{l}\text { Bending } \\
\text { strength } \\
\mathrm{rb}_{\mathrm{b}}(\mathrm{kPa})\end{array}$ & $\begin{array}{l}\text { Ice load }{ }^{2} \\
\text { Q }(\mathrm{MN})\end{array}$ \\
\hline $\begin{array}{l}\text { DS410, 1945 } \\
\text { (and to 1977) }\end{array}$ & $353^{1 /-}$ & & 1.20 \\
\hline VBS publ. 21979 & $1250 / 3000$ & $500 /-$ & 4.25 \\
\hline DS410, 1982 & $1200 / 2500$ & 500/1200 & 4.08 \\
\hline DS410, 1998 & $1600 / 2500$ & 500/1200 & 5.11 \\
\hline $\begin{array}{c}\text { Tillæg DK:2015 Islast } \\
\text { (and DK:2009, } \\
\text { DK:2013) }\end{array}$ & $1900 / 1900$ & $\mathbf{5 0 0} / 500$ & 5.78 \\
\hline \multicolumn{4}{|c|}{$\begin{array}{l}\text { Votes: } \\
\text { Back calculated (Svendborgsundbroen pier 10,13) to match EQ. (1 } \\
\text { with } \mathrm{e}=0.6 \mathrm{~m} \text {. } \\
\text { Svenborgsundbroen, piers } 11,13 \text {, EQ. (1), d = } 4.1 \mathrm{~m} \text { and Code as } \\
\text { lefthand column. }\end{array}$} \\
\hline
\end{tabular}

The stream piers 10 and 13 of Svendborgsundbroen from 1962 (Fig. 2) may illustrate the consequences of the changing rules. Using a pier width of $4.1 \mathrm{~m}$ and an average span width of $40 \mathrm{~m}$, the resulting characteristic ice loads are as shown in Table 1 right-hand column.

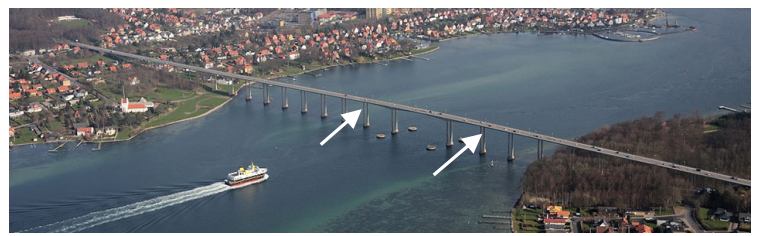

Fig. 2. Svendborgsundbroen, Denmark (arrows indicate stream piers 10 and 13 adjacent to the main span piers)
It is difficult to understand the rationale behind the change in the rules leading to ever-increasing ice loads despite a trend of increasingly milder winter seasons. Ice breaking in inner Danish waters has not been carried out in recent years and the last state owned ice-breaking ships were sold in 2015 .

\section{Strength of ice}

As evidenced by Table 1 the compressive strength of ice required by the rules is uncertain. The strength depends primarily on the type of ice, crystal size and orientation, air content, salinity, temperature, strain rate and interface to structure. However, the resulting ice strength varies considerably from country to country, from reference to reference and not least due to the basic parameters needed together with a priori assumptions.

The salinity, $S_{B}$, of the water is a very important input parameter as seen in Table 1. Going from the North Sea $\left(S_{B}>30 \%\right)$ over the interior Danish waters $\left(S_{B} \sim 11\right.$ to $22 \%$ ) to the Baltic Sea $\left(S_{B} \sim 9 \%\right)$ and the Bay of Bothnia $\left(S_{B}<5 \%\right.$ o to the north), the salt content drops very considerably as seen in Figure 3.

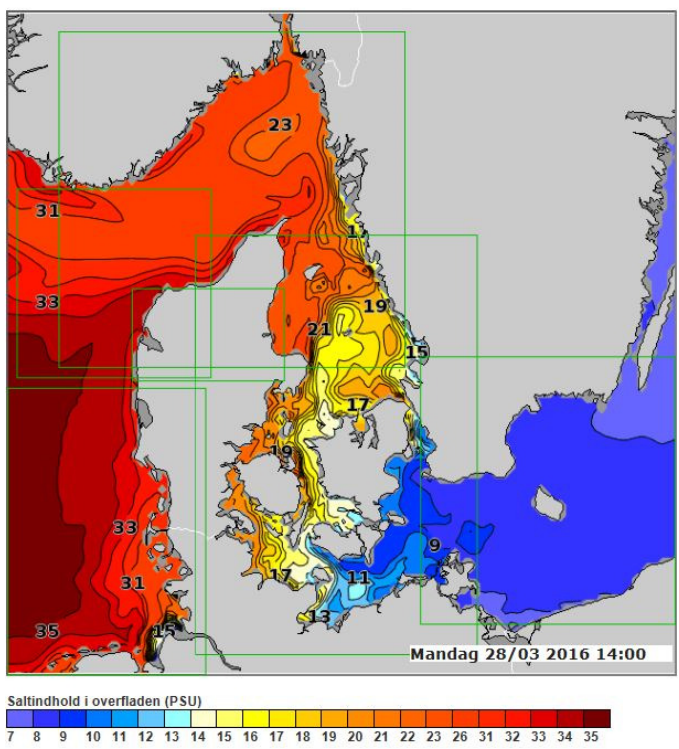

Fig. 3. Salinity (\%o) around Denmark and the Baltic Sea (DMI 2016)

EAU (2012) indicates an equation for derivation of the (horizontal) compressive strength of ice (for lack of specific requirements in the German Annex to Eurocode EN 1990 (DIN EN 1990/NA 2012):

$$
\begin{aligned}
\varphi_{B} & =19.37+36.185\left(S_{B}\right)^{0.91}\left|\vartheta_{m}\right|^{-0.69} \\
\sigma_{0} & =270 \dot{\varepsilon}^{1 / 3} \varphi_{B}{ }^{-1} .
\end{aligned}
$$

The parameters are: $\varphi_{B}$, porosity (\%o), $S_{B}$, Salinity (\%o), $\vartheta_{m}$, mean temperature of ice $\left({ }^{\circ} \mathrm{C}\right), \dot{\varepsilon}$, strain rate at impact of ice and structure $\left(\mathrm{s}^{-1}\right)$ and $\sigma_{0}$, horizontal uniaxial compressive strength $(\mathrm{MPa})$. Without specific indications, the 
bending strength is suggested as $1 / 3$ of the compressive strength. This is in agreement with the recommendations of a factor 0.26 by IEC (2005). The compressive strength doubles for a factor 10 increase in strain rate up to the most onerous value of $\dot{\varepsilon}=10^{-3}$.

Burchart (2004) refers to Timco, Frederking (1986) for the compressive strength, $\sigma_{0}$, and Weeks and Assur (1969) for the bending strength, $\sigma_{f}$ :

$$
\begin{aligned}
\sigma_{0}= & 39 \dot{\varepsilon}^{0.26}\left(1-(v / 320)^{0.5}\right) ; 10^{-5} \leq \dot{\varepsilon} \leq 10^{-3} \\
\sigma_{f}= & 0.75\left(1-\left(v_{b} / 0.202\right)^{0.5}\right) \\
v= & v_{a}+v_{b} \\
v_{b}= & \left(0.532-49.185 / T_{i}\right) S_{i} ; \\
& -22.9^{\circ}<T_{i}<-0.5^{\circ} .
\end{aligned}
$$

The parameters are: $v_{\mathrm{a}}, v_{\mathrm{b}}$, relative volumes of air and salt (pure number), $T_{i}$, ice temperature $\left({ }^{\circ} \mathrm{C}\right), S_{i}$, ice salinity (pure number). The water salinity is $v_{\mathrm{a}}$.

The ice salinity is difficult to assess as it decreases with ice thickness and decreasing air and water temperature but it seems likely that for an ice thickness $<0.6 \mathrm{~m} S_{i}$ $\geq 7 \%$ o (in Danish waters).

For the case of Svenborgsundbroen (see Table 1) the compressive strength would be $1.4 \mathrm{MPa}$ according to Eq. (2), but $0.78 \mathrm{MPa}$ according to Eq. (3) for a salinity of the water of $19 \%$, a mean temperature of the ice of $2^{\circ}$, a salinity of the ice of 7\%o and the most onerous strain rate of $10^{-3}$. In both cases, the bending strength is roughly $1 / 3$ of the compressive strength.

\section{Ice strength from other countries}

Although the recommendations regarding the ice strength vary considerably there seems to be universal acceptance of an approximate ratio of $1 / 3$ between the bending and compressive strength. The only exception is Sweden (Vägverket 1987) where the ratio attains an anomalous value of 1.5 to 3 as the bending strength is given as $1 \mathrm{MPa}$ for the Swedish west coast and $2 \mathrm{MPa}$ for the Baltic Sea. These values are also found in Bergdahl (2002) where reference is made to the Russian SNIP 11-57-75 (1980) using a bending strength of $2 \mathrm{MPa}$.

In many countries (Canada, USA, Norway, Poland) the compressive strength of the ice is stated for fresh water only and for sea water ice, "specialist advice should be sought". The Norwegian Håndbok 185 bruprojektering (2015) indicates that the compressive strength of sea ice may be taken as $2 / 3$ of the value for fresh water ice.

Strength indications from various sources are summarized in Table 2 but mostly for fresh water ice where the rule of thumb of $2 / 3$ for seawater may be applied. This emphasises the need for site-specific considerations. However, as demonstrated above, there is considerable uncertainty associated with the decisive parameters used

\begin{tabular}{|c|c|c|}
\hline Source & $\begin{array}{c}\text { Compressive } \\
\text { strength } \\
\mathrm{r}_{\mathrm{c}}(\mathrm{kPa})\end{array}$ & Comment \\
\hline $\begin{array}{l}\text { Vägverket } \\
\text { (1987) }\end{array}$ & $\begin{array}{l}-/ 700 \\
-/ 1400 \\
\mathbf{5 0 0} /-\end{array}$ & $\begin{array}{l}\text { Regulated rivers, mid to } \\
\text { north Sweden } \\
\text { Large floes }{ }^{1} \text {, strong cur- } \\
\text { rent, high velocity } \\
\text { West coast of Sweden }\end{array}$ \\
\hline $\begin{array}{c}\text { PN-85-S-10030 } \\
(2010)\end{array}$ & $-/ 750$ & For moving ice \\
\hline $\begin{array}{c}\text { DNV-OS-J101 } \\
(2010)\end{array}$ & $\begin{array}{l}1600 /- \\
1900 /-\end{array}$ & $\begin{array}{l}\text { Southern North Sea, } \\
\text { Skagerak, Kattegat } \\
\text { South-western Baltic }\end{array}$ \\
\hline $\begin{array}{c}\text { CAN/CSA-S6-06 } \\
(2015)\end{array}$ & $\begin{array}{l}-/ 700 \\
-/ 1100 \\
-/ 1500\end{array}$ & $\begin{array}{c}\sim \text { melting, disintegrated } \\
\sim \text { melting, large floes, } \\
\text { sound } \\
<\text { melting, large floes. } \\
\text { sound } \\
\text { Specialist advice for sea } \\
\text { water }\end{array}$ \\
\hline $\begin{array}{l}\text { AASHTO LRFD } \\
(2004,2012)\end{array}$ & $\begin{array}{c}-/ 770 \\
-/ 1150 \\
-/ 1530\end{array}$ & $\begin{array}{c}\sim \text { melting, disintegrated } \\
\sim \text { melting, large floes, } \\
\text { sound } \\
<\text { melting, large floes. } \\
\text { sound } \\
\text { Specialist advice for sea } \\
\text { water }\end{array}$ \\
\hline EAU (2004) & $\begin{array}{l}1500 /- \\
1800 /- \\
-/ 2500\end{array}$ & $\begin{array}{c}\text { North Sea } \\
\text { Baltic Sea } \\
\text { Fresh water }\end{array}$ \\
\hline EAU (2012) & Eq. (2) & $\begin{array}{c}\text { To be calculated based } \\
\text { on equation }\end{array}$ \\
\hline $\begin{array}{c}\text { Håndbok } 185 \\
\text { bruprojektering } \\
(2015)\end{array}$ & $\begin{array}{c}\mathbf{( 2 0 0 0 ) / 3 0 0 0} \\
(\mathbf{6 6 7}) / 1000\end{array}$ & $\begin{array}{c}\text { Floes }^{1} \text {, coldest part of year } \\
\text { Partly weakened, near } \\
\text { melting point }\end{array}$ \\
\hline
\end{tabular}
for calculation of site-specific ice strength in Eqs (2) and (3) as also demonstrated by the values in Table 1.
Table 2. Ice strength for sea water/fresh water from various sources

Note: ${ }^{1}$ The rules do not define large floes, small floes or floes.

The conclusion from the indications in Table 2 is that the current Danish rules advocating a compressive strength of $1900 \mathrm{kPa}$ is very conservative considering the relatively high values of salinity and temperatures in effect in the Danish waters.

\section{Ice thickness}

The ice thickness depends primarily on the number of Freezing Degree Days, FDD and the water salinity. However, local conditions (interlaced layers of fresh water, bathymetry etc.) can play an important role.

$F D D$ is the absolute value of the product of the sum of days with 24 hours below zero temperature and the average temperature (days ${ }^{\circ} \mathrm{C}$ ). According to Burchart (2004) the ice thickness, $e$, for inner Danish waters is:

$$
e=0.03 \sqrt{F D D-50} \text {. }
$$


The 50 days ${ }^{\circ} \mathrm{C}$ subtracted accounts for the number of days required to cool the water areas to temperatures close to the freezing point.

The average maximum ice thickness (from 1906 to 2010), based on FDD (maximum of 497.5 in the winter 1941-42) from six measuring stations for the Danish inner waters, is shown in Figure 4. The data comprise 62 winters with $e>0$. Fitting the data to a normal distribution results in a mean value of $e_{\text {mean }}=0.24 \mathrm{~m}$ with a standard variation of $0.14 \mathrm{~m}$.

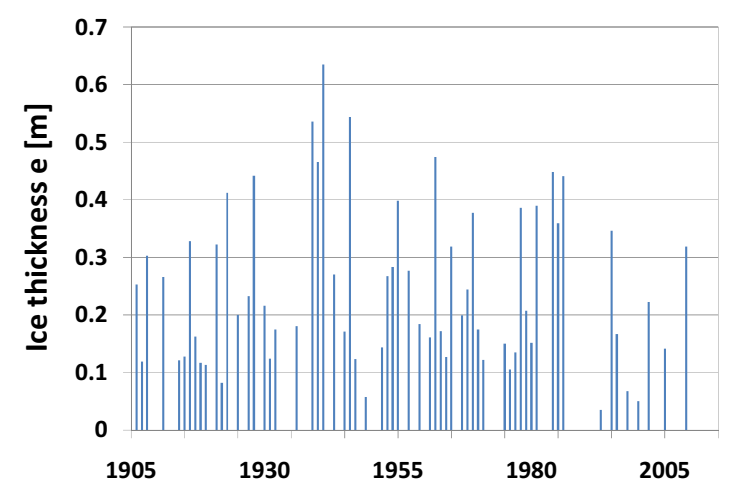

Fig. 4. Average ice thickness in inner Danish waters based on Freezing Degree Days, FDD (Eq. 4)

According to recommendations for offshore wind turbine support structures (IEC 2005), the thickness estimate is:

$$
e=0.032 \sqrt{0.9 F D D-50} \text {, }
$$

where the factor 0.9 on $F D D$ is an empirical factor. This results in $e_{\text {mean }}=0.25 \mathrm{~m}$, i.e. the same as above.

It may be argued that a log-normal distribution is more suitable as negative ice thickness of course is not possible. However, neither distribution is a "perfect" fit as seen in Figure 5.

The data from Figure 4 are shown together with theoretical normal and log-normal cumulative probability functions. The log-normal distribution provides a better fit for small ice thicknesses, whereas the normal distribution fits much better for larger ice thicknesses. The normal distribution is therefore used to estimate the ice thickness for a 50 year return period of $e_{\max }=0.53 \mathrm{~m}$.

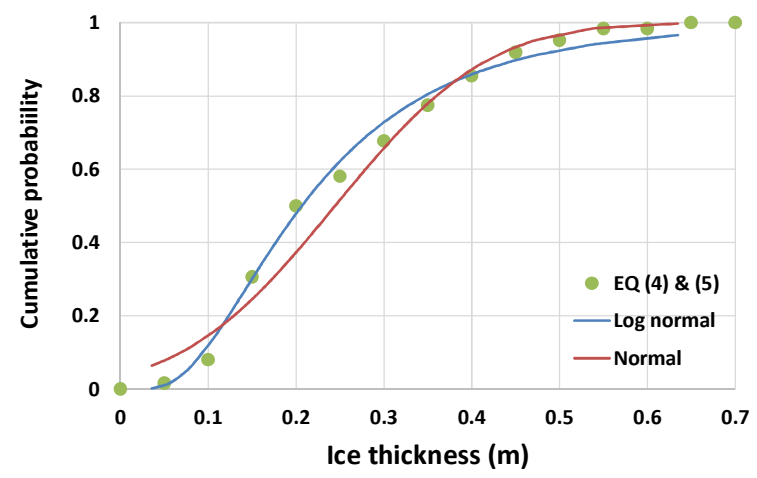

Fig. 5. Cumulative probability of ice thickness from Figure 4
Thus, the recommendations in the Danish rules is conservative, particularly considering the well-establish-ed trend of increasing local and global temperature.

Bergdahl (2002) reports on ice thickness variations in 18 areas from Skagerak to the top of the Bay of Bothnia during the 16 years from 1963 to 1979 (measurements day 1,11 and 21 every month).

The mean and maximum ice thickness were $11 \mathrm{~cm}$ and $21-30 \mathrm{~cm}$, respectively, for areas south of Ystad and west of Varberg. In contrast ice thickness mean (and maximum) were $52 \mathrm{~cm}(>73 \mathrm{~cm})$ and $28 \mathrm{~cm}(57-72 \mathrm{~cm})$ for the areas east northeast of Skellefteå and south southeast of Umeå, respectively.

This lends credence to the above contention that the current Danish rules are conservative.

\section{Ice winters}

The normal conception of an ice winter (in Denmark) was active duty for at least one day by one of the (maximum six) state-owned icebreakers. The first of these, "Isbjørn", was operational in 1923. Due to the limited power of the ships in the past, Danish waters were often impassable by ships and ice boats were used for postal service across Storebælt up to 1893 and from 1922-29. The most onerous winters were 1798-99, 1799-80 and 1829-30 where ice transport was necessary for 108,114 and 104 days, respectively.

Figure 6 shows the 24 coldest winters in terms of the mean temperature from December to March versus FDD data from 1906 to present.

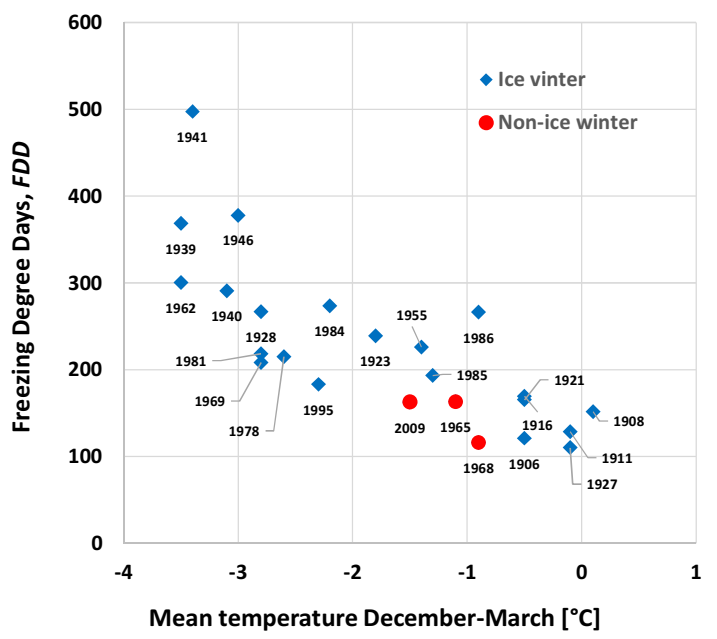

Fig. 6. Twenty-four coldest winters in terms of mean temperature since 1905 (Non-ice winters 2009-10, 1965-66 and 1968-69)

Only three of these were not pronounced ice winters, despite obvious difficulties for the shipping transport (in non-ice winters) as evidenced from Figure 7 in Øresund during the 1954-55 winter. It is evident from Figure 6, that for $F D D<100$ there is no ice winter.

For the ice winter of $1995-96(F D D=183.2)$ the ice breaker Thorbjørn was on duty as seen in Figure 8 . 


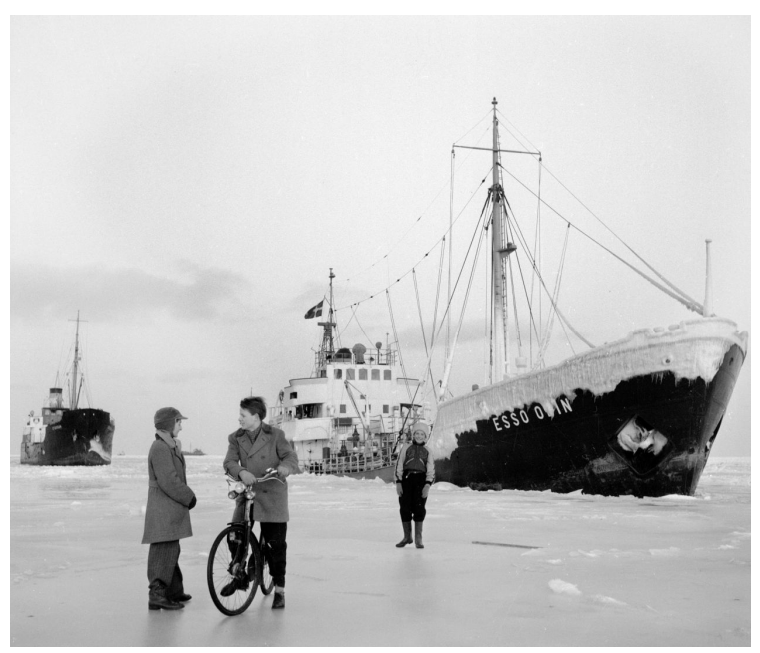

Fig. 7. Ice problems in Øresund, winter of 1954 (Photo by Aage Sørensen)

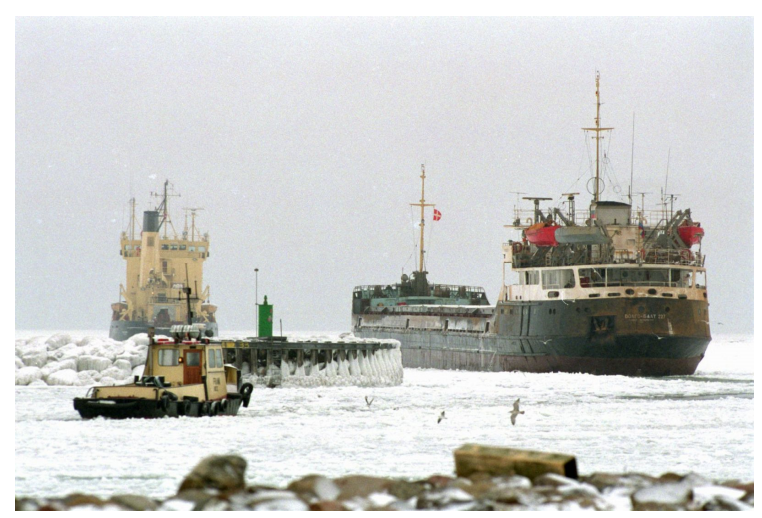

Fig. 8. Ice breaking by Thorbjørn, winter of 1995-96 (Photo by Jacob Dall)

\section{Extreme considerations}

As a matter of curiosity, the results from an extremevalue analysis, carried out for the ice in Storebælt for the Great Belt West Bridge (see Fig. 9), may be considered in the light of future design of large bridge structures in Denmark.

Using an extremely low exceedance probability of $210^{-5}$ (50 000 year return period) and neglecting climate trends, an ice thickness of $0.99 \mathrm{~m}$ and a corresponding compressive strength of the ice of $2.8 \mathrm{MPa}$ was found (Christensen, Skourup 1991).

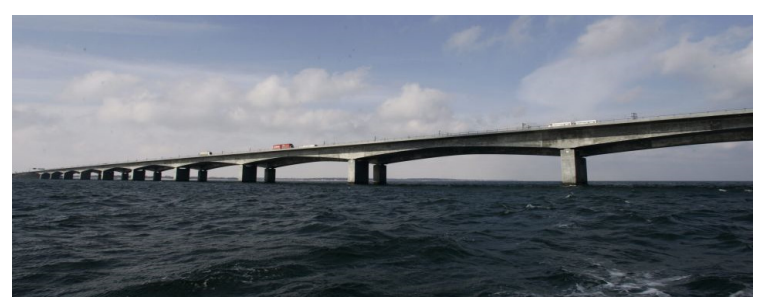

Fig. 9. Storebælt, West Bridge, Denmark
One may just wonder if bridges and traffic will exist within this kind of time frame (another ice age or global warming?).

\section{Swedish rules for calculation of ice impact}

The recommendations in Vägverket (1987) seem still to be valid for use in Sweden and these formed the basis for the author's original interest in the subject.

Due to the proximity to Denmark (Swedish west coast in particular), it is logical to compare with the Danish rules.

Interestingly, the load on bridge piers are calculated as was done in the Danish rules prior to 1979.

The geometry definitions appear from Figure 10 and the loads on the bridge pier in the middle are:

$$
\begin{array}{ll}
I_{2}=i_{2}\left(L_{1}+L 2\right) / 2 & \text { (smaller floes) } \\
I_{2}=C_{1} \sigma_{k} d b & \text { (large floes) } \\
I_{1}=i_{1} a &
\end{array}
$$

where (symbols in brackets indicate Danish nomenclature in DS410 1998):

$-i_{2} \quad 10-30 \mathrm{kN} / \mathrm{m}$ for fresh water;

$-L_{1}, \quad L_{2}$ centre-centre distance to neighbouring piers;

$-C_{1}$ shape factor with tabled values for $\mathrm{b} / \mathrm{d}\left[k_{3}\right]$, see Figure 11;

$-\sigma_{k}$ compressive strength of ice $(\mathrm{MPa})$, see Table $2,\left[r_{c}\right]$;

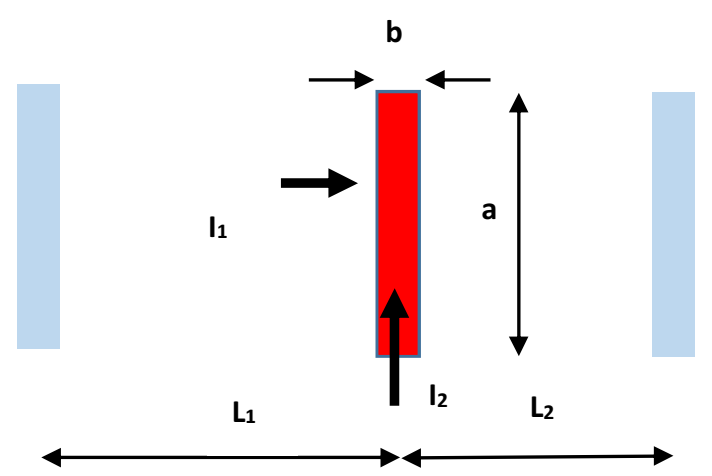

Fig. 10. Geometry definitions (Vägverket, 1987) with current in the direction of $\mathrm{I}_{2}$

$-d$ ice thickness (m), [e];

$-b$ width of pier shaft $(\mathrm{m}),[d]$;

$-i_{1}$ thermal ice pressure $50-300 \mathrm{kN} / \mathrm{m}$ fresh water;

$-a$ width of pier shaft perpendicular to alignment.

The rules give no guidance on the size of "smaller" and "large" floes. This is left open to the interpretation of reader. 


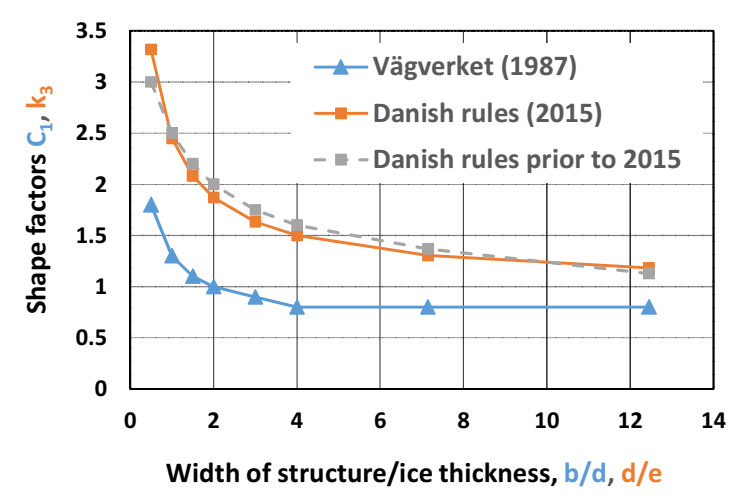

Fig. 11. Shape factors, $C_{1}$ and $k_{3}$, in Swedish and Danish rules

Using Svendborgsundbroen (see Table 1) as an example, the total characteristic ice load would be less than $0.23-0.68 \mathrm{MN}$ for smaller floes and 2.62 or $\mathbf{0 . 9 4} \mathrm{MN}$ for large floes $(\mathrm{L} 1+\mathrm{L} 2=80 \mathrm{~m}$, ice thickness $0.57 \mathrm{~m}$ and $\sigma_{k}=1400 \mathrm{kPa}$ or $500 \mathbf{~ k P a}$, the latter for Swedish west coast).

A very significant reduction in ice load would result using Swedish rules and further reduction would be achieved if the ice thickness was reduced to the more reasonable value of $0.53 \mathrm{~m}$.

\section{Measures to reduce ice load on structures}

An obvious structural feature is introduction of an inclined front such as ice-load reducing cones on offshore wind turbine foundations. This is standard for bridges in more severe climates as the Confederation Bridge in Canada, Figure 12.

Introduction of an inclined front on the structure significantly reduces the ice load, as the ice breaks up, due to the lower bending strength. The vertical and horizontal components of the ice load may be found using the formula by Ralston (1977) quoted in many references and adopted by API. Pragmatically, Bergdahl (2002) indicates a reduction factor for the horizontal load, $k_{4}$, as a function of the slope of the cone, $\alpha$, with vertical, $k_{4}=0.75$ for $15^{\circ} \leq \alpha<30^{\circ}$ and $k_{4}=0.50$ for $30^{\circ} \leq \alpha \leq 45^{\circ}$.

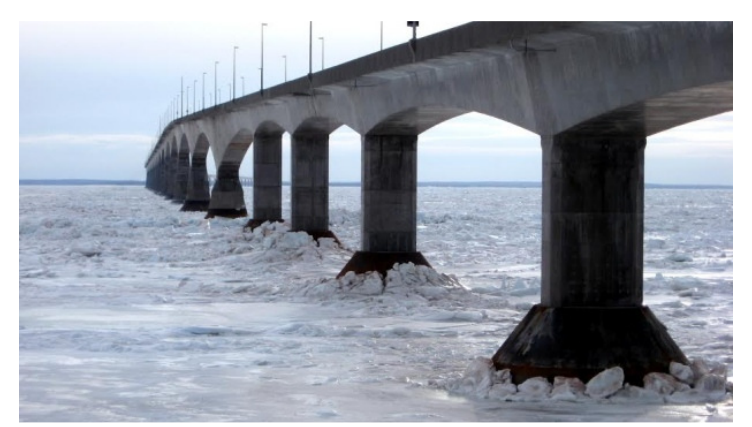

Fig. 12. Confederation Bridge, Canada, with ice cones subjected to ice loading

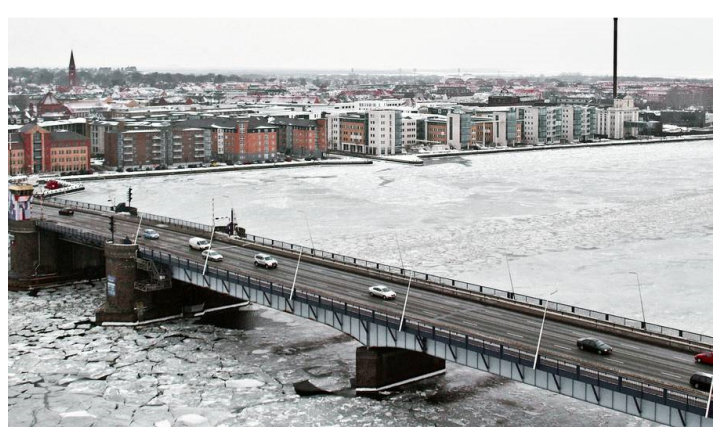

Fig. 13. Limfjordsbro with point nosed pier to cleave the ice (winter 2009-10)

Likewise introduction of a pointed nose of the pier may reduce the ice impact very considerably due to cleavage of the ice floe. This is illustrated by Figure 13 for the Limfjordsbro in Aalborg, Denmark, where the flow of ice is dictated by the narrow width of the Fjord.

If the onerous Danish rules (in terms of ice thickness and strength) are maintained, then provision of ice cones or "ice breaking equipment" akin to the waterair jetting equipment on modern ice breakers may be required to reduce ice loads to manageable magnitude.

\section{Case histories where Danish rules were waived}

\section{New Royal Theatre in Copenhagen}

For the $0.6 \mathrm{~m}$ diameter piles for the New Royal Theatre, Figure 1, the characteristic horizontal ice load adopted was $360 \mathrm{kN}$, compared to $1140-2250 \mathrm{kN}$ (DS410 1998) or 234-328 kN (Vägverket 1987).

The Danish rules were waived for a balanced compromise between Danish and Swedish rules. This allowed for a do-able design and took heed of the observed (negligible) impact on harbour structures in the past.

\section{Svendborgsundbroen}

For Svendborgsundbroen, Figure 2, the recommended horizontal characteristic ice loads on the stream pier (cf. Table 1) was 2.8 MN for fixed, frozen ice and 1.9 MN for moving ice (COWI 2012). These values were adopted as a balanced weighing of the Danish 2009 rules (comparable to the 2015 rules) and the Swedish rules (Vägverket 1987). Using the current Danish rules (Bane-Danmark, Vejdirektoratet 2015) a value of 5.8 MN would be obtained.

\section{New pedestrian bridge across Copenhagen harbour}

In the design of a new pedestrian bridge (2005) across the inner harbour of Copenhagen moving ice floes were ruled out and the ice impact was restricted to impact from ice breaking in the harbour (Fig. 14).

The pivot piers had conical shape allowing reduction of ice impact according to the recommenddations in Annex E of IEC (2005) as this was (and is) not included in the Danish rules. For the $\varnothing 1 \mathrm{~m}$ dolphin protection piles, the Danish rules were applied but with a reduced 
ice thickness of $0.3 \mathrm{~m}$, as this was the limit for ice breaking activities according to the harbour officials. As a consequence, the compressive strength of the ice was reduced to $r_{c}=1.0 \mathrm{MPa}$ commensurate with a five year return period.

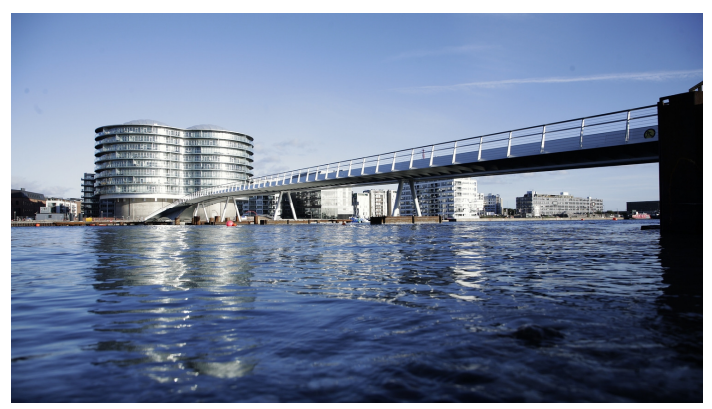

Fig. 14. Pedestrian bridge across the inner harbour, Copenhagen

\section{Ice breaking Bryghusgrunden, Copenhagen}

Project Bryghusgrunden is currently well under way in Copenhagen harbour as one of the few "undeveloped" harbour front areas. An artist's view is seen in Figure 15.

The assessor questioned the ice impact on the basement wall, which was based on the thermal expansion of $46 \mathrm{kN} / \mathrm{m}$ for a $0.6 \mathrm{~m}$ thick ice. The issue was the ice load from ice breaking in the harbour.

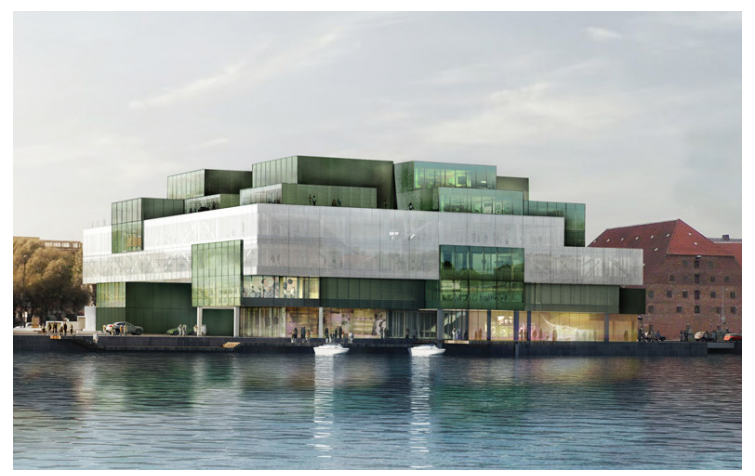

Fig. 15. Project Bryghusgrunden, Copenhagen harbour front

Although ice breaking per say will not take place for an ice thickness above $0.3 \mathrm{~m}$, passage of ships ( 5 passages per year) with oil for the power plant further into the harbour may require ice breaking by the ship. The ship typical of the five ships passing is shown in Figure 16 when breaking ice in the Bay of Riga.

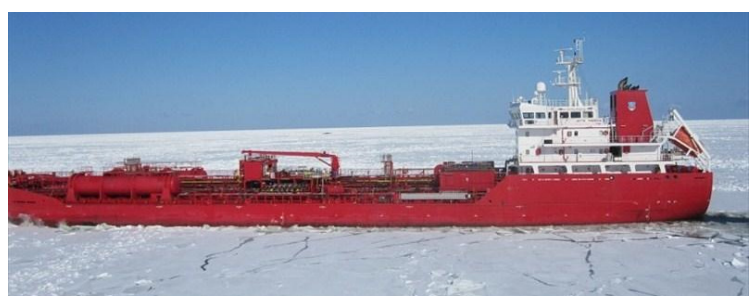

Fig. 16. "Bitten Theresa" typical of ships passing the Copenhagen harbour front with oil to the power plant
From videos on Youtube and photos of icebreakers passing persons on the ice, only a few metres away it would appear that the crushing of the ice by the stern is much localised (see Fig. 17).

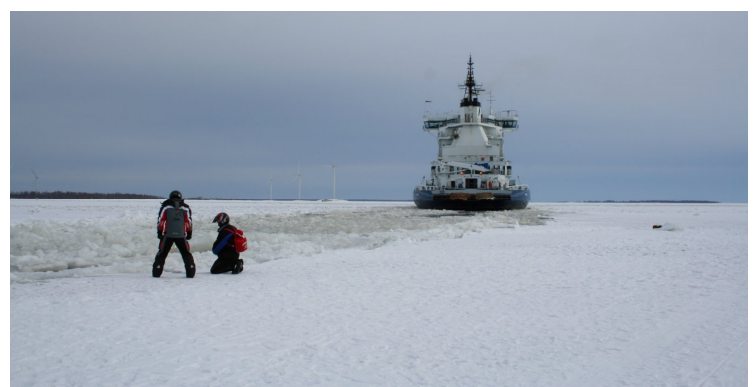

Fig. 17. "By-standers" close to ice broken by ice breaker

Thus, a very simplified calculation of possible ice impact from the passage of a ship as "Bitten Theresa" at a minimum distance of $45 \mathrm{~m}$ from the basement wall is shown schematically in Figure 18.

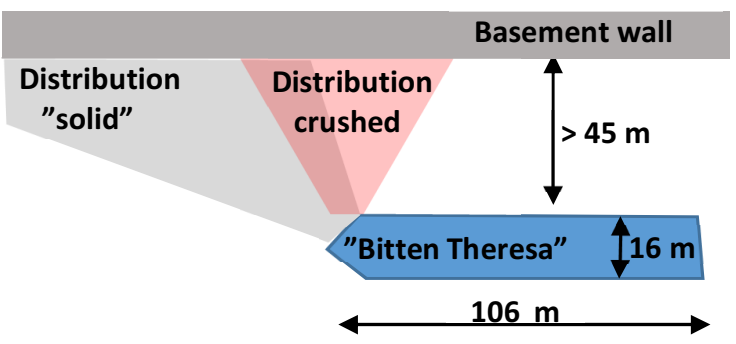

Fig. 18. Principle of ice pressure distribution from stern

As an approximation the $8 \mathrm{~m}$ stern length (bulb) produces an ice pressure perpendicular to the ship movement in crushed ice using a pressure distribution of 1:2 or alternatively a distribution through intact ice from the approximated stern front under 45 degrees with the sailing direction.

Thus, the factor, $k_{2}$, in Eq. (1) takes the value of 0.5 for the first case and 1.0 for the second.

Assuming an ice thickness of $\mathrm{e}=0.3 \mathrm{~m}$ and $r_{c}=$ 1.0 $\mathrm{MPa}$ result in average ice pressures perpendicular to the basement wall of $22.6 \mathrm{kN} / \mathrm{m}$ and $22.3 \mathrm{kN} / \mathrm{m}$ for the two scenarios, respectively. Thus, the applied thermal pressure of $46 \mathrm{kN} / \mathrm{m}$ is more onerous than the ice loading from ice breaking.

\section{Conclusions}

The assessment of ice impact on structures is not straightforward. Although there seems to be reasonable consensus regarding the overall principles by application of shape and model factors, very considerable confusion exists regarding the determination of the critical ice compressive and bending strength. 
The latter is exacerbated by the fact that many countries only provide rules for fresh water ice without guidance for the marine environment.

The Danish rules for ice impact on structures have been examined in terms of the historical evolvement and international rules. Irrespective of no reported failures due to ice loading and a trend towards less severe winters, the Danish rules show a very pronounced trend of ever increasing values for the compressive strength of ice to be applied. Looking at the bridge pier example in Figure 2, this corresponds to a five-fold increase of the horizontal ice load due to moving ice from 1945 to 2015.

The consideration of ice impact as an ULS event with a high partial load factor (1.5) and a $\mathrm{K}_{\mathrm{FI}}$ factor of 1.1 for major bridges further increases the design load. As major bridge projects are ongoing in Danish waters the current rules may significantly influence the cost of the foundation structures and thus the overall project costs unless ship impact is more onerous than ice impact.

The main conclusion is that there is room for a very critical review of the way ice impact on structures is treated in the Baltic Marine environment.

\section{Acknowledgements}

The author gratefully acknowledges the financial support from COWI to publish the paper.

\section{Disclosure statement}

The Author has no competing financial, professional, or personal interests from other parties.

\section{References}

AASHTO LRFD. 2004. Bridge Design Specifications (SI). American Association of State Highway and Transportation Officials.

AASHTO LRFD. 2012. Bridge Design Specifications (Customary US units), American Association of State Highway and Transportation Officials.

Banedanmark, Vejdirektoratet. 2015. Tillceg DK: 2015 Islast.

Bergdahl, L. 2002. Islaster på vindkraftverk til havs. Rapport nr. 2002:1. Chalmers Tekniska Högskola, Göteborg.

Burchart, H. F. 2004. Islaster på konstruktioner. 4 Udgave. Aalborg Universitet.

CAN/CSA-S6-06. Canadian highway bridge design code. Canadian Standards Association, 2015.

COWI. 2012. Svendborgsundbroen, Islast. Document No. 54780-U-36-001 submitted to the Danish Road Directorate.

Christensen, F. T.; Skourup, J. 1991. Extreme ice properties, Journal of Cold Regions Engineering 5(2): 51-68.

http://dx.doi.org/10.1061/(ASCE)0887-381X(1991)5:2(51)
DIN EN 1990/NA, National Annex to EUROCODE: Basis of structural design, 2012.

DNV-OS-J101. Design of offshore wind turbine structures. Det Norske Veritas, 2010.

DMI [online]. 2016 [cited 28 March 2016]. Avialable from Internet: http://www.dmi.dk/hav/udsigter/havprognoser/

DS410. 1945, 1959, 1965. Normer for Bygningskonstruktioner, 1. Belastningsforskrifter. 1 Udgave March 1945. (1959 and 1965 editions are reprints of the 1945 edition).

DS410. 1982. Last på konstruktioner. 3 Udgave. Teknisk Forlag, København.

DS410. 1998. Norm for last på konstruktioner [Code of Practice for Loads for the Design of Structures]. 4. Udgave. Danish Standard Association, Copenhagen.

EAU. 2004. Empfehlungen des Arbeitsausschusses "Ufereinfassungen", Häfen und Wasserstraßen. 10 Auflage. Ernst \& Sohn, Berlin.

EAU. 2012. Empfehlungen des Arbeitsausschusses "Ufereinfassungen", Häfen und Wasserstraßen. 11 Auflage. Ernst \& Sohn, Berlin.

Håndbok 185. 2013. Bruprojektering. (Høringsutgave 2013-0111). Statens vegvesen (Norwegian public roads).

IEC. 2005. IEC 61400-3:2005, Annex E (Informative) Recommendations for design of offshore wind turbine support structures with respect to ice loads (in Wind Turbines Part 3: Design requirements for wind turbines). International Electrotechnical Commission.

PN-85-S-10030. Obiekty mostowe. Obciażenia (Bridges. Loads). Polska Norma, 2010.

Ralston, T. D. 1977. Ice Force Design Considerations for Conical Offshore Structures, in Proc. of the $4^{\text {th }}$ International Conference on Port and Ocean Engineering under Arctic Conditions (POAC77), 26-30 September 1977, Newfoundland, Canada, 2: 741-752.

SNIP-11-57-75. 1980. Construction standards and rules. Part 2. Design standards, Chapter 57: Loads exerted on hydraulic structures by waves, ice and ships. Translated from Russian, Moscow. Gosstroyizdat, 1976 CRREL, Acc. No. 36003849.

Timco, G. W.; Frederking, R. M. W. 1986. Confined compression tests: Outlining of the failure envelope of columnar sea ice, Cold Regions Science and Technology 12(1): 1328. http://dx.doi.org/10.1016/0165-232X(86)90016-9

VBS. 1979. Last på havnekonstruktioner. Publikation nr. 2. Vandbygningsteknisk Selskab.

Vägverket. 1987. Istryck mot bropelare. Publ. 1987:43. Vägverket, Serviceafdeling Väg- och Brokonstruktion.

Weeks, W. F.; Assur, A. 1969. The mechanical properties of sea ice. Cold regions Science and Engineering. Part II: Physical Science. Section C: Physics and Mechanics of Ice. Cold Region Research and Engineering Laboratory, Hanover, N.H. 